\title{
A Case of Primary Colon Carcinoma Demonstrated by FDG PET/CT Imaging After Detection of a Solitary Brain Metastasis
}

\author{
Soliter Beyin Metastazının Saptanmasından Sonra FDG PET/BT ile Primer Kolon Karsinomu \\ Gösterilen Bir Olgu
}

\author{
Seval Erhamamc, Mehmet Reyhan, Gül Nihal Nursal, Neşe Torun, Ali Fuat Yapar \\ Başkent University Faculty of Medicine, Department of Nuclear Medicine, Ankara, Turkey
}

\begin{abstract}
The detection of brain metastases as the initial manifestation of colorectal carcinoma without liver or lung involvement is extremely rare. Herein we present a case of a 52-year-old male patient with an unusual presentation of colon cancer, with primary lesions demonstrated by fluorine-18-labeled fluorodeoxyglucose (FDG) Positron-emission tomography/computed tomography (PET/CT) after detection of a solitary brain metastasis. Brain CT images revealed a brain tumor. Histopathologic evaluation indicated metastatic poorly differentiated adenocarcinoma, while his physical examination was normal. The PET/ CT revealed abnormal intense FDG uptake in the right parietal region and in descending colon, with no other abnormal FDG uptake elsewhere in the body. The histopathologic diagnosis of the descending colon lesion revealed moderately differentiated adenocarcinoma. This case indicates that FDG PET/CT imaging may have a positive impact on the evaluation of patients with brain metastasis from an unknown primary.
\end{abstract}

Key Words: Positron-emission tomography/computed tomography, brain tumor, colon cancer, unknown primary tumors

Conflicts of Interest: The authors reported no conflict of interest related to this article.

\section{Özet}

Karaciğer veya akciğer tutulumu olmaksızın kolorektal karsinomunun ilk klinik bulgusu olarak beyin metastazının görülmesi son derece nadirdir. Burada, soliter beyin metastazının saptanmasından sonra, primer lezyonu flor-18-işaretli fluorodeoksiglukoz (FDG) Pozitron-emisyon tomografi/bilgisayarlı tomografi (PET/BT) ile gösterilen nadir kolon kanserli 52 yaşında erkek bir olguyu sunduk. Beyin BT görüntülerinde, beyin tümörü saptandı. Histopatholojik inceleme metastatik az diferansiye adenokarsinomayı gösterdi. Fizik muayene normaldi. PET/BT sağ parietal bölgede ve inen kolonda yoğun FDG tutulumu gösterdi, vücudun başka bir yerinde anormal FDG tutulumu izlenmedi. İnen kolondaki lezyonun histopatolojik tanısı orta diferansiye adenokarsinoma ile uyumluydu. Bu olgu, FDG PET/BT görüntülemenin primeri bilinmeyen beyin metastazlı hastaların değerlendirilmesinde olumlu etkiye sahip olabileceğini gösterdi.

Anahtar Kelimeler: Pozitron-emisyon tomografi/bilgisayarlı tomografi, beyin tümörleri, kolon kanseri, bilinmeyen primer tümörler

Çıkar Çatışması: Yazarlar bu makale ile ilgili olarak herhangi bir çıkar çatışması bildirmemiştir.

Address for Correspondence: Seval Erhamamcı MD, Başkent University Faculty of Medicine, Department of Nuclear Medicine, Ankara, Turkey Phone: +90 3322570606 E-mail: sevaler@yahoo.com Received: 12.06.2013 Accepted: 27.07.2013 


\section{Introduction}

Approximately $15-20 \%$ of patients with colorectal cancer (CRC) harbor distant metastases at the time of diagnosis. The most common metastatic sites for CRC are the liver, lungs and peritoneum. Brain metastases (BM) from CRC is rare in comparison to other common malignancies, such as lung, breast, and renal carcinoma. Brain metastases occur in $1-3 \%$ of patients with CRC at the time of diagnosis, and in up to $10 \%$ of patients during subsequent disease course $(1,2)$. Usually, the development of BM is the terminal stage of colorectal carcinoma and generally occurs in patients with extensive metastatic disease.

The development of new modalities such as fluorine18-labeled fluorodeoxyglucose (FDG) positron emission tomography combined with computed tomography (PET/CT) has contributed to the evaluation of various types of cancer, and the benefits of FDG PET/CT for cancer staging are well established. Previous studies have reported diagnostic contribution of whole-body FDG PET/CT scan in the evaluation of patients with unknown primary cancer, and suggested early utilization of this method to optimize patient diagnosis and management $(3,4)$. FDG PET/CT detects more metastatic sites than other modalities and discloses the site of the primary tumor in $20-40 \%$ of cases $(5,6)$.

In this report, patient with an unusual presentation of colon cancer, with primary lesions demonstrated by FDG $\mathrm{PET} / \mathrm{CT}$ after detection of a solitary BM without any liver or lung involvement. This case indicates that FDG PET/CT imaging may have a positive impact on the evaluation of patients with brain metastasis from an unknown primary.

\section{Case Report}

A 52-year-old male patient, with a clinical history of diabetes mellitus, was admitted to the hospital due to left hemiparesis. Cranial computed tomography (CT) showed a solitary lesion located at the right parietal region. The patient underwent craniectomy and excisional biopsy. Histopathologic evaluation demonstrated the cerebral lesion to be a metastatic poorly differentiated adenocarcinoma. His initial work-up included physical examination, laboratory and imaging studies. Blood chemistry did not reveal any remarkable abnormalities, including tumor markers, such as carcinoembryonic antigen (CEA), carbonhydrate antigen (CA) 19-9 and CA 15-3. Tumor markers and thorax ve abdominal $\mathrm{CT}$ failed to identify the primary site.

The patient was referred to Nuclear Medicine Department for FDG PET/CT, in order to localize the primary tumor. FDG PET/CT whole body scan (Discovery-STE 8; General Electric Medical System, Milwaukee, Wisconsin, USA) was performed 60 minutes after intravenous injection of $403.3 \mathrm{MBq}(10.90$ $\mathrm{mCi}$ ) of FDG. FDG PET/CT images showed increased metabolic activity in the descending colon at the left abdominal region and in the right parietal region of the brain (Figure 1). No other abnormal FDG uptake was detected elsewhere in the body. Colonoscopy was performed and the histopathologic examination revealed an adenocarcinoma. The patient underwent whole brain radiotherapy (WBRT) for a total dose of $30 \mathrm{~Gy}$ in 10 fractions. Subsequently, subtotal colectomy was performed. Pathologic examination of the resected tissue revealed a moderately differentiated adenocarcinoma that infiltrated the serosa and pericolonic fat with mucinous differentiation in less than 30\%. Metastatic adenocarcinoma was detected in mesenteric lymph nodes with lymphovascular invasion (T3N1M1). The patient was eventually diagnosed with stage IV adenocarcinoma of the descending colon and was started on systemic chemotherapy. The patient underwent only one cure of chemotherapy. He died due to systemic complications of the disease at four months after the diagnosis of brain metastasis.

\section{Literature Review and Discussion}

Brain metastases are the most common intracranial tumors, and occur in about $10-40 \%$ of all cancer patients $(1,7)$. In the last decade, the detectability of BM has increased owing to improvements in radiologic techniques and in survival rates due to multimodality therapies that led to an increase in the risk of developing BM (8). It is reported that up to one third of patients with BM do not have a previous cancer history (9). Additionally, in up to $10 \%$ of patients, even after a timeconsuming and costly workup, the primary tumor site remains unknown (10). At initial presentation, up to $63 \%$ of the patients have multiple tumors, while $37-50 \%$ present with a single BM (11). Approximately $80 \%$ of lesions are found in the cerebrum, $15 \%$ in the cerebellum, and $5 \%$ in the brain-stem.

Brain metastases from CRC are rare and usually tend to appear in the late course of the disease, coexisting with liver or lung metastases in most cases $(1,8)$. The venous drainage of the bowel is via the portal system resulting in the liver to be the main site for metastases, followed by the lungs. At later

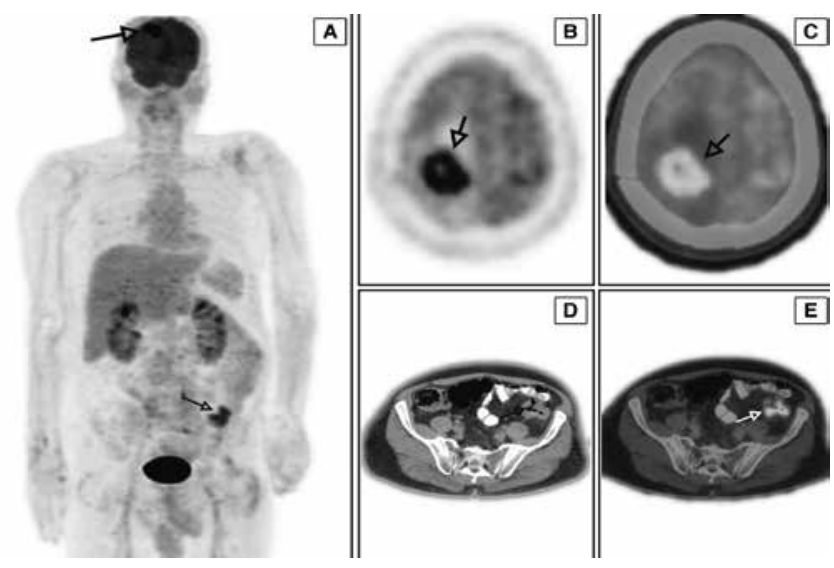

Figure 1. Maximum intensity projection (A), axial PET (B), fusion (C), computed tomography (D), and fusion (E) images showed increased metabolic activity in the thickened left descending colon (thin arrows), and right parietal lobe (bold arrows). However, no other abnormal FDG uptake was observed elsewhere in the body 
stages, tumor cells enter the systemic circulation and spread to any organ system. Within these systems, BM are infrequent $(1,12,13,14)$. Central nervous system metastases are more common in rectal cancer as compared to colon cancer since its venous drainage is into the inferior vena cava, therefore by-passing the liver, but in such cases lung metastases are more frequent (8). In other words, BM that is associated with liver or lung metastases are more frequent than isolated BM.

Solitary BM as the initial manifestation of primary colon carcinoma without any liver or lung involvement is extremely rare, with only few cases reported in the literature $(12,13,14)$. In this case report, we present a male patient with solitary BM secondary to adenocarcinoma of the descending colon without any other organ involvement.

In patients with BM, detection of the primary tumor may optimize treatment planning and improve patient outcome. Indeed, some studies have shown that survival in patients in whom a primary tumor was eventually detected was higher than in patients in whom the primary tumor remained undetected $(9,10)$. Additional diagnostic procedures that can be used for primary tumor detection include a combination of various radiologic, endoscopic, and serum tumor marker studies, depending on the specific signs and symptoms, histological and laboratory abnormalities. However, these tests can be expensive, timeconsuming and invasive. Furthermore, in the majority of patients these tests may eventually fail to detect a primary tumor (10). Clearly, there is a need for an alternative, noninvasive imaging modality with a high diagnostic yield. The development of FDG PET/CT has contributed to the evaluation of cancer staging and detection of unknown primary tumor origins $(3,4,5,6)$. FDG PET/CT can also identify additional sites of metastases that can alter the patient's management, which probably improves survival time and at the same time can serve as a guide for biopsies, as shown in our patient. Many researches have shown that FDG PET is a useful tool to locate the primary lesion, both in patients with metastases in the head and neck region and in patients with extra-cervical metastases (3).

The prognosis of patients with BM from CRC is dismal. The median survival after the diagnosis of $\mathrm{BM}$ is reported as 2.7-8.3 months (2). There is controversy regarding the best treatment for patients with BM. Some patients benefit from a multidisciplinary management strategy. The main treatment modalities for single brain metastases are WBRT, surgery and stereotactic radiosurgery $(15,16)$. The patient presented herein underwent surgery, WBRT and systemic chemotherapy, but unfortunately, he died four months after the initial diagnosis of BM.

In conclusion, we report a rare patient with primary colon carcinoma detected by FDG PET/CT following identification of a solitary brain metastasis. FDG PET/CT whole body imaging is both a noninvasive and a very sensitive tomographic whole-body imaging modality, allowing for the detection of a primary tumor and complete tumor staging all in one single examination, which may contribute substantially to selecting appropriate therapeutic methods and evaluating prognosis.

\section{References}

1. Schouten LJ, Rutten J, Huveneers HA, Twijnstra A. Incidence of brain metastases in a cohort of patients with carcinoma of the breast, colon, kidney, and lung and melanoma. Cancer 2002;15:2698-2705.

2. Kruser TJ, Chao ST, Elson P, Barnett GH, Vogelbaum MA, Angelov L, Weil RJ, Pelley R, Suh JH. Multidisciplinary management of colorectal brain metastases: A retrospective study. Cancer 2008;113:158-165.

3. Kwee TC, Basu S, Cheng G, Alavi A. FDG PET/CT in carcinoma of unknown primary. Eur J Nucl Med Mol Imaging 2010;37:635-644.

4. Yapar Z, Kibar M, Yapar AF, Paydas S, Reyhan M, Kara O, Buyukdereli G, Aydin M, Kelle AP, Unal I, Disel U, Yavuz S, Sahin B, Erkisi M. The value of 18F-fluorodeoxyglucose positron emission tomography/ computed tomography in carcinoma of an unknown primary: diagnosis and follow-up. Nucl Med Commun 2010;31:59-66.

5. Pelosi E, Pennone M, Deandreis D, Douroukas A, Mancini M, Bisi G. Role of whole body positron emission tomography/computed tomography scan with 18F-fluorodeoxyglucose in patients with biopsy proven tumor metastases from unknown primary site. Q J Nucl Med Mol Imaging 2006;50:15-22.

6. Karapolat I, Kumanlıoğlu K. Impact of FDG-PET/CT for the Detection of Unknown Primary Tumours in Patients with Cervical Lymph Node Metastases. Mol Imaging Radionucl Ther 2012;21:63-68.

7. Jenkinson MD, Haylock $B$, Shenoy $A$, Husband $D$, Javadpour $M$. Management of cerebral metastasis: evidence-based approach for surgery, stereotactic radiosurgery and radiotherapy. Eur J Cancer 2011;47:649-655.

8. Mongan JP, Fadul CE, Cole BF, Zaki BI, Suriawinata AA, Ripple GH, Tosteron TD, Pipas JM. Brain metastases from colorectal cancer: risk factors, incidence, and the possible role of chemokines. Clin Colorectal Cancer 2009;8:100-105.

9. Agazzi S, Pampallona S, Pica A, Vernet O, Regli L, Porchet F, Villemure JG, Leyvraz $S$. The origin of brain metastases in patients with an undiagnosed primary tumour. Acta Neurochir (Wien) 2004;146:153157.

10. Bartelt S, Lutterbach J. Brain metastases in patients with cancer of unknown primary. J Neurooncol 2003;64:249-253.

11. Linskey ME, Andrews DW, Asher AL, Burri SH, Kondziolka D, Robinson PD, Ammirati M, Cobbs CS, Gaspar LE, Loeffler JS, McDermott M, Mehta MP, Mikkelsen T, Olson JJ, Paleologos NA, Patchell RA, Ryken TC, Kalkanis SN. "The role of stereotactic radiosurgery in the management of patients with newly diagnosed brain metastases: a systematic review and evidence-based clinical practice guideline," J NeuroOncol 2010;96:45-68.

12. Succi L, Urrico GS, Prumeri S, Politi A, Latteri F. Brain metastasis: first sign of colorectal carcinoma. Chir Ital 2000;52:419-420.

13. Gómez Raposo C, Mora Rillo M, Gómez Senent S, Robles Maruhenda A, Montoya F, García Puig J, González Barón M. Brain metastases as the first sign of colon cancer. Clin Transl Oncol 2007;9:742-743.

14. Ruiz-Tovar J, Tartas A, Ramos JL, Miramón J, Limones M. Cranial metastases: first sign of colorectal cancer. Is the resection of the primary non-complicated tumour indicated when the metastases have been resected? Clin Transl Oncol 2010;12:154-156.

15. Nieder C, Pawinski A, Molls M. Prediction of short survival in patients with brain metastases based on three different scores: a role for 'triple-negative' status? Clin Oncol (R Coll Radiol) 2010;22:65-69.

16. Siu $T L$, Jeffree RL, Fuller JW. Current strategies in the surgical management of cerebral metastases: an evidence-based review. J Clin Neurosci 2011;18:1429-1434. 